\title{
The Vanguard of Colonialism: Missionaries and the Frontier in Southern Africa in the Nineteenth Century
}

\author{
Paul Gifford
}

\begin{abstract}
In this essay, I undertake an examination of how Christian missionary societies facilitated the spread of European ideals and belief systems within an African community, and how this spread both prepared and weakened the African polities for increasing contact with colonial authorities. I specifically explore the role missionaries took in everyday functioning of African chiefdoms and kingdoms through their roles as interpreters and diplomats. Missionaries played a role in shaping the day-to-day existence of the polities in which they were based, as they saw themselves fighting in the "war for souls" in Africa. I examine the effects of this contact in syncretising African and European beliefs, focusing on the especially tragic example of the Xhosa cattle killing. Life on the frontier shaped a deterministic "Christian" identity amongst white settlers along the fringes of colonial life, a distance which in turn led to these fringe groups being seen as un-Christian by their own churches.
\end{abstract}

While the role played by missionaries in communication and diplomatic relations between colonial forces and indigenous societies in Africa is well known, there has been a dearth of in depth examinations of the role which individual missions and missionaries had in the construction of a new sense of identity post-contact. The stated goal of missionary activity was to save the souls of the supposedly barbaric peoples of Africa and to bring the 'light of European civilisation.' However, the missions would prove to be the vanguard of European contact. In the earliest days of the colonial enterprise in Africa, mission societies were amongst the only groups willing to provide funding, outside the centres of colonial authority, and to find willing participants in these expeditions. It is interesting to note, then, that the first white men that many African societies were to encounter were there not to learn about them but to change them. Whatever their stated goals, missionary work within the interior was the softer, first wave of conquest, preparing the groundwork for the imposition of a European style of rule, familiarising Africans with the language and tradition of their future rulers. While some of the mission societies would have certainly challenged this assertion, they were not there for humanitarian purposes. In this paper, I plan to address the role which missionaries had in changing the fundamental nature of African societies in southern Africa in the period leading up to the assumption of more direct control by British authorities. To this end, I will be looking at several interconnected themes. First, I will examine the role which missions played in the political dynamics of the region, serving initially as interpreters and advisers and ultimately making themselves invaluable in the external political dealings of a chiefdom. Second, I will examine the effect which mission activity had on the fundamental spiritual beliefs of Africans through the lens of the great Xhosa cattle killing of the mid-nineteenth century. The syncretist background of this movement, combining elements of Christian and Xhosa theology, provide an excellent brief case study of the shift. I will then examine the homogenising effect which mission work had during the latter part of the nineteenth century. Through an examination of early Boer culture, and in particular the shift which occurred in their conception and presentation of themselves. 


\section{The War for Souls}

British missionary activity grew out of the burgeoning Evangelical movement that had developed over the course of the eighteenth century, and was tied into the anti-slavery movement which was coming to prominence at the end of that century. At the conclusion of the Seven Years War Britain found itself in possession of a great number of new territories around the world and in a position as the unquestioned master of the seas. There was a growing sense amongst the British middle class that black Africans were not irredeemably barbaric, as had been the earlier sense, but were doomed only by their lack of God; that is to say, the lack of a specifically Christian God. ${ }^{1}$ As Evangelical Christianity gained a more general acceptance, with its less hierarchical structure and its call for the uplifting of all mankind through an embrace of moral, Christian values and the ending of chattel slavery in the colonies became a rallying point. ${ }^{2}$ Britain's government would come to agree, and would pass a series of anti-slavery laws in the first decades of the nineteenth century. ${ }^{3}$ The efforts of the anti-slavery movement had been successful, and while Africans were often still cast in the mould of uncivilised barbarians, they were coming to be seen instead as 'noble savages.' A key component of the Evangelical credo is the spread of a moral form of Christianity, and as the industrial revolution brought relative prosperity to a great many Britons and ushered in the growth of a burgeoning middle class, those of an Evangelical bent began to see Africa as their calling. Missionary societies began to form with the intent of sponsoring expeditions to African territory, to "save souls" and bestow God's blessing on Africa. ${ }^{4}$

It was in this context that the first missionary societies were formed. While the situation on the ground in southern Africa was one of conflict and frequent violence, at least between colonising groups and the local polities, missionary societies began to construct an image wherein Africa was, until recent times, an Edenic garden, free from the sufferings of mortal man. ${ }^{5}$ Because of the perceived naiveté of Africans, the missionaries believed that Africa had only recently become "corrupted," and that whatever sinister force was behind this corruption could be corrected through God. Thus, what was in truth a fairly common situation, of conflict in a frontier zone, was now portrayed as something so much more: a battleground between God in the form of Christian missionaries, and Satan. ${ }^{6}$ With such a setting it is small wonder that those bent on spreading the word of God would be eager to travel to Africa, despite their absolute ignorance of the languages and cultures of the area they were traveling to. Even death in the course of spreading the Word would be an agreeable ending, as death while doing the work of God was an instant pass to a blessed afterlife. This may not have been a major draw for those of a higher socio-economic class and wealth who led the missionary societies, but certainly the appeal for those of a poor labourer's background is obvious.

The missionary's purpose once within Africa was twofold. First, the missionaries hoped to convert the chiefs and leaders of the region, as they believed that conversion of the chiefs could function "like Constantine to the Romans" and convert their people en masse. ${ }^{7}$ Second, the missionaries hoped that, eventually, their message would spread enough that they would be able to turn loose

\footnotetext{
1 Norman Etherington, The Great Treks: The Transformation of Southern Africa 1815-1854 (London: Pearson Education Limited, 2001), 8.

2 Elizabeth Elbourne, Blood Ground: Colonialism, Missions, and the Contest for Christianity in the Cape Colony and Britain 17991853 (Montreal: McGill-Queen's University Press, 2002), 15.

${ }^{3}$ Piers Brendon, The Decline and Fall of the British Empire, 1781-1997 (London: Random House, 2007), 23-29.

${ }^{4}$ Elbourne, The Great Treks, 13.

${ }^{5}$ Etherington, Blood Ground, 8.

${ }^{6}$ Ibid., 95.

7 Ibid., 202.
} 
newly Christianised and Europeanised Africans out into the frontier to convert their brethren. ${ }^{8}$ Unlike the imperial authorities in the Cape, missionaries espoused a credo which was theoretically intended to better the lives of those to whom they preached, and their calls for peace and love between fellow man were certainly in stark contrast to the policy from colonial sources. However, as is so often the case when looking at the long, troubled history of colonial Africa, what the missionaries claimed they were there to do and what actually occurred are often at odds. While often directed at chiefs, this is not to say that there no direct mission activity with the peasants of African polities. Take for example the Xhosa settlement on the Kat River, wherein the local peoples were made to live in square, multi floor European dwellings and dress in what could only have been in this climate the intensely hot and uncomfortable European style dress. These were not the missions which received the most support and funding.

As the purpose of mission activity was to interact directly with Africans, it was essential that missionaries learned the local languages of the peoples they were interacting with, a process which in many cases also facilitated a missionary-created orthography for the purposes of translating the Bible for distribution. 'Because of the increasingly widespread nature of missionary activity, they soon became the standard go to translators and interpreters for contact between African leaders and the colonial authorities as they tried to deal with the local polities. Initial contact with missionaries was largely seen as harmless by the chiefs, as despite the constant critique of their hosts' beliefs and cultures they were perceived as ridiculous, dressed in stifling hot black robes speaking of strange concepts with such a fervent passion. In time, thanks to their knowledge of the languages and, to some extent at least, the cultures of those with whom they dealt, they came to be regarded in some sense as the European equivalent of a hostage exchange. By having priests on both sides serving as interpreters and advisors, their presence became interpreted as a guarantor of good faith in negotiations. It was not long before it also became readily apparent that the presence of friendly missionaries was a serious boon to any chief who could secure representation at his court, as it was in the best interests of the missionaries to present the society which hosted them as in a state of improvement thanks to their presence. Positive reports of the growing presence of proper civilisation could help to secure greater access to goods, and more likelihood of a positive outcome in diplomacy. Where before there was chaos and terror, thanks to the civilising influence of mission work the states in which they lived were now becoming paragons of stability in an otherwise barbaric land. A prominent example is a group of French missionaries who, taking the metaphorical term of "eating up" another man [and his territory] at face value, declared that cannibalism had been rife in the area as recently as a decade or two prior, but had been eradicated thanks to their presence. This, of course, conveniently ignored the local abhorrence of the dead, and the lack of any person who could directly remember such a time. ${ }^{10}$

When the benefits of a missionary presence became apparent, chiefs began to court the missionaries in an attempt to gain both their sympathy and therefore a good word in dealings with the colonial authorities. Ultimately, the goal of most chiefs would seem to have been to gain access to the guns and horses which the missionaries brought, and while it was rare that they could receive them it was in the best interests of both parties to play along. So long as the missions were tolerated, or even encouraged, positive word of the progress towards civilisation of the host society would be conveyed back to the Cape. Despite the fact that many Africans in the period were still secure in their beliefs and their traditional way of life, the mission societies were faced with such an increasing

\footnotetext{
${ }^{8}$ Etherington, The Great Treks, 95.

${ }^{9}$ Ibid., 58.

10 Ibid., 38-9.
} 
demand for missionaries that they were at times forced to turn down requests from chiefs due to the simple lack of people to send. ${ }^{11}$ Which is not to say that they were entirely unable to cope with said demand, merely that the qualifications of new missionary recruits was, somewhat inevitably, bound to become lowered. Unlike early missionaries, such as the Dutchman J.T. van der Kemp, a highly educated former professional soldier who spoke at least seven languages, by the 1820s and 1830s it was becoming more common to find young men fresh into the world in the frontier. ${ }^{12}$ Naturally this affected the way in which the new missionaries viewed the territory and the culture they were entering. The welcome given to a young missionary visiting the court of Mzilikazi is an excellent example, as in the young man's account there is talk of how the chief would parade dozens of naked dancing women to inflame the passions of his warriors. ${ }^{13}$ Certainly some measure of the described scene is accurate, but one cannot help feel that the account would have been rather more sombre (and perhaps, realistic) if presented by someone with more experience in the world. It is equally striking that while the missionaries, as the only major European presence outside of British controlled territory at the Cape, were regarded as experts of a sort on African dynamics, those arriving at the courts of influential chiefs seem to always give off the impression that the chiefs were much more aware of the politics of the region than the missionaries. ${ }^{14}$ As is so often the case, it is clear that the situation was far more complex than presented, and while missionary accounts would certainly lead the reader to believe that they were an integral part of cultural dynamics and the return to their supposed Eden, the true picture can emerge nonetheless. All of this is not to say that Africans were inherently opposed to the idea of conversion, nor that the missionaries had failed wholesale at their efforts. One need look no further than settlements like that at the aforementioned Kat River for proof. While looking at the spread of Christianisation it is simply imperative to remember that it was in the best interests of the chiefs to portray themselves as interested in Christianity and as helpful in its spread as they could, and it was in the best interests of the missionaries to report as much success as possible. Funding and support would be directed towards successful missions, not failures.

\section{They Come From Across the Water}

Throughout the nineteenth century African polities were to see a gradual erosion of their power as the British were to move further past the Cape frontier. While the spread of European diseases and the like was relatively minimal along the Cape frontier, there was nonetheless a change beginning in African cultures which resulted in perhaps as much destruction as could be seen in many of the American colonies of centuries past. ${ }^{15}$ In much of the traditional African spiritual life, there was no separation between a religious and a secular life; rather the supernatural was all around them. There was no need for a day of worship or regularised prayers, because one could have contact with the gods and the spirits at all times. ${ }^{16}$ However, as chiefdoms retreated further and further inland and more Africans found themselves under the declared authority of the British, with their old beliefs outlawed or ridicule, it is small wonder that Africans might have begun to feel that their belief system was failing them in the face of this onslaught. Due to the heavy missionary infiltration into

\footnotetext{
11 Ibid., 193.

12 Elbourne, Blood Ground, 92-96.

13 Etherington, The Great Treks, 200.

14 Ibid., 191-3.

15 This comparison is especially fruitful in the treatment of indigenous peoples of the Spanish colonies during the $16^{\text {th }}$ and $17^{\text {th }}$ centuries.

16 Vansina, Jan. "A Clash of Cultures: African Minds in the Colonial Era." African History: From Earliest Times to Independence $2^{\text {nd }}$ ed. Eds. Philip Curtin, Steven Feierman, Leonard Thompson, Jan Vansina (Essex: Pearson Education Limited, 1995), 469-70.
} 
the interior over the past half century, many Africans were familiar with the core concepts of Christianity. ${ }^{17}$ Given missionaries' perception of Africa as a battleground for the souls of Africans, there was an added stress on the millenarian aspects of Christian theology. Indeed, a core element of Evangelical thought was the desire to convert all the heathens so that Jesus could return from heaven and bring all good Christians back to life in the end of days. ${ }^{18}$ This belief in the end of days and the return of the hallowed dead to life would have resonated with contemporary Xhosa, as similar concepts existed in their spiritual thought. The chaos of recent years, combined with the missionaries preaching a similar doctrine, merely confirmed to many that this day was near. ${ }^{19}$

Prior to the arrival of European settlers, the Xhosa chiefdoms had been amongst the most powerful and widespread in the Cape region, but over the course of a devastating series of wars throughout the eighteenth and nineteenth centuries they had found much of their territory annexed and their leaders marginalised. It is no surprise that they might search for a reason behind the end of their traditional ways of life amidst this series of horrifying events. Signs of this shift in Xhosa worldview were visible as early as the 1810 s, in the form of the prophet and diviner Nxele. Having spent time on a Dutch farm as a youth, he was well acquainted with colonial practices and Christian theology, and on his return to Xhosa lands he took up trade in the more mystic aspects of Xhosa culture. While he saw himself as akin to Christian missionaries, and tried to cultivate friendships with them, the steady creep of British territorial claims, and concurrent dismissal of his powers eventually forced a change in his thinking. Soon he was talking about a conflict between good and evil in the Cape, but in a warped reflection of the missionaries teachings, he claimed that the corrupters were in fact the white men, who had been banished to Africa for the killing of Jesus, and that the black man's god would soon drive them out. ${ }^{20}$ By 1818 Nxele had gained enough of a following to try to bring this about, with disastrous results. Nxele was banished, most of his followers were dead in battle, and the British aligned Xhosa chief in the area was forced to cede a huge swath of territory to "secure the border." 21 Despite Nxele's failure, this admixture of African and Christian theology would persist, resurfacing with tragic results three decades later in the form of a young prophetess named Nongqawuse.

The spread of this syncretic version of Christian theological teachings would continue to become ever more prevalent within Xhosa society, as would the spread of those who explicitly declared themselves to be "Christian." 22 While the depth of their conversion can perhaps be up to question, there is no doubt that these chiefs were often set apart by their new faith. As has been mentioned previously, the missionaries' belief in a last battle between good and evil for the souls of mankind had entered into Xhosa consciousness, and while the missionaries may have thought of themselves as the front line of God's side, the Xhosa saw things in a very different manner. While Nxele was ineffective in his attempts to push the white men out of Africa, his ideas lived on, and were spurred by word coming in from the outside. Most dramatic was the response of the Xhosa to news of the Crimean War. As J.B. Peires relates, when news reached the Xhosa that their former Governor had died at the hands of the Russians in the Crimean War, the reaction was surprising, though perhaps

\footnotetext{
${ }^{17}$ Elbourne, Blood Ground, 78.

${ }^{18}$ Etherington, The Great Treks, 198-10.

19 J.B. Peires, The Dead Will Arise: Nongqawuse and the Great Xhosa Cattle Killing Movement of 1856-7 (Bloomington: Indiana University Press, 1989), 72-3.

20 Ibid., 33.

${ }^{21}$ Etherington, The Great Treks, 64-5.

22 While these chiefs would declare themselves to be Christians and followers of the Word of God, as is so often the case their interpretation of Christianity in some respects different from the strict Orthodoxy of the missionaries. Much the settler communities of Dutch origin, how readily accepted they were by Christian authorities was debatable.
} 
an understandable one. As the Xhosa had heard neither of the Russians, nor the Crimean War prior to this, they were free to interpret events as they saw fit. As such, the Russians became the avenging spirits of the Xhosa ancestors, coming to sweep the white men from Africa. While this never occurred, it speaks to how strongly the idea of a coming final battle had become invested in Xhosa world view. This coming apocalypse was to manifest itself again the next year in an immediate and terrifying manner: the cattle lung sickness, better known to European settlers as rinderpest. Brought from Europe on trading ships, the lung sickness was a disease which ravaged the breathing of affected cattle, making the process a torturous and painful one and eventually preventing them from eating, so that over the course of a few weeks they starved to death. The sickness had a long incubation period, and thus was almost impossible to prevent the spread of infected cattle making their way across the countryside. By the time symptoms manifested themselves, half of the herd could have become infected. As the Xhosa herds slowly began to die off, the idea of this ancestral army waiting across the sea to come and save the Xhosa combined with the increasingly large scale devastation, and saw the first prophets and prophetesses coming forth with the progenitors of the coming destruction in the form of various plans for salvation from the sickness. ${ }^{23}$ As the prevention of the lung sickness was only possible by quarantining herds and culling those infected already, the measures certainly made some sense, but ultimately they were insufficient to stave off the coming epidemic.

The various threads of this building conflict came together when the orphaned, fifteen year old niece of an important Xhosa chief was supposedly visited by the spirits of several honoured ancestors in 1856. As has been mentioned previously, it is extremely important to remember that in African cosmology the supernatural is all around, and that for an otherwise relatively inconsequential person to be visited by the honoured ancestors was if not commonplace, at least undeserving of special surprise. The girl, Nongqawuse, claimed that the spirits had told her of a solution to all of their problems. She relayed that the ancestors claimed the cattle had been infected by the corrupting touch of those practicing witchcraft, that all the cattle had to be removed, and that all of their accoutrements and decorations were to be reforged. When this had been completed, the ancestors would come from across the sea, and new healthy cattle would arise from the banks of the Kei river. ${ }^{24}$ The desperation of the Xhosa was compounded by the conditions of that year: there was an unusually long drought followed by rains which destroyed much of the crops, an infestation by a small bug crippled much of the maize harvest, and even the birds seemed more determined to destroy the crops. ${ }^{25}$ While initially many of the infected cattle were simply traded or slaughtered for food, when the originally appointed day for the coming of the ancestors came and passed, more extreme measures were adopted. Nongqawuse and her patron uncle claimed that the ancestors had not returned because their commands had not been followed to the letter, and that before they would return the cattle must now be culled en masse through ceremonial sacrifice to the ancestors, and no plantings could be undertaken for the new growing season. ${ }^{26}$ Aside from buying time for the growing influence Nongqawuse and her uncle now held amongst the Xhosa chiefs, this move also left room for shifting the blame off of them should another date come and go. Clearly, any holdouts were to blame, for all the Xhosa must participate before the end of days would come. Interestingly, despite the links to Christian theology as espoused by the missionary groups, it is striking that many of the doubters of this prophecy were those chiefs who identified as Christian. Certainly the

\footnotetext{
23 Peires, The Dead Will Arise, 70-5.

${ }^{24}$ Ibid., 79-81.

25 Ibid., 71.

${ }^{26}$ Ibid., 98-9.
} 
government at the Cape was eager to prevent the mass slaughter of cattle, and one can't help but think that this connection may have been an element in their disbelief.

While initially many Xhosa were happy and eager for the new order to come, as time wore on it became clear that something would have to occur soon, as they quite simply were rapidly running out of food. Another date for the coming of the ancestors was set in 1857, and predictably it came and went with no world shaking events. When the others tried to find Nongqawuse and her uncle, they were (also somewhat predictably) nowhere to be found, having left a message saying simply that the ancestors had left out of disgust at the lack of cooperation of the unbelievers. ${ }^{27}$ While by now the movement had begun to lose steam, and believers began to flock away, it was too late. Numbers are hard to ascertain with any certainty, but it is estimated that as many as 40,000 Xhosa were to die in the ensuing famine, with as many as another 33,000 moving into the Cape, which is thought to be more than three quarters of the independent Xhosa population at the time. ${ }^{28}$ In the end, attempts to stave off a disaster ended in a tragedy of an even greater scale. While they had managed to retain a fair measure of their cultural and political independence, this was the death blow to Xhosa power, and in the following decades they were largely subsumed into the Cape Colony.

\section{Heathens and Sinners of the Chosen People}

While African polities were being exposed to Christianity directly for the first time, they were not the only targets of the epithet heathen; the previous generations of white settlers along the frontier were to share that dubious distinction. Over the years many amongst the settlers, most especially those who belonged to the Dutch Reformed Church in southern Africa, had come to view themselves not as those banished from the chosen lands, as the Africans had come to see them, but rather as God's chosen people. ${ }^{29}$ As with so much else in the region, the settlers interpreted their journeys through the lens of Biblical allegory, and had begun to view their wanderings across the veldt as akin to the wanderings of the Israelites across the desert, even before the Great Trek of the 1830s had begun. Because of the nature of their settlement, many of the farmers were hundreds of kilometres away from the centres of colonial authority, and therefore cut off not just from direct administration but also from direct access to law and the church. As a frontier society the need for literacy was minimal, and while most Boers of the period would have at least claimed some familiarity with the Bible, it is unlikely that most had ever in fact read it. It is with little surprise, then, that one must realise that religious practices outside the bounds of the established orthodoxy would become the new norm. In the developing settler thought, it was heresy to teach the local Africans to read and practise Christianity, since Christianity was the domain of God's chosen peoples. Because the Africans were born without Christianity, they would die damned. ${ }^{30}$ While it is debatable just how widespread this and the associated idea that, as God's chosen people, it was their right to treat the land and the people inhabiting it as they saw fit, there is little doubt that some held strongly to such beliefs, and would cause trouble when they were challenged. ${ }^{31}$ Of course, these sorts of beliefs did not fit into established Church orthodoxy anywhere outside of southern Africa, and in fact many missionary societies officially viewed the Boers and other white settlers as, at best, nominal Christians. As one missionary related, those who claimed Christianity but did not practice it (according to missionary conceptions, at least) were worse than the unconverted Africans. For at

\footnotetext{
27 Ibid., 150.

${ }^{28}$ Leonard Thompson, A History of South Africa (New Haven: Yale University Press, 2000), 79.

${ }^{29}$ Susan Newton-King, Masters and Servants on the Cape Eastern Frontier (Cambridge: Cambridge University Press, 1999$), 7$.

${ }^{30}$ Ibid., 188

31 See especially the accounts of J.T. van der Kemp in his preaching along the settler frontier. Elbourne, Blood Ground, 130-6.
} 
least the Africans did not know that they were living in $\sin .^{32}$ This antipathy was often shared in reverse. ${ }^{33}$

In stark contrast to the views of those settlers who espoused Christianity, strict adherence to missionary orthodoxy was of paramount importance to African converts, as through proper belief lay relief from the poverty and despair which gripped many mid century. With the mass of upheavals and wars that gripped the Cape and its frontiers in the late eighteenth and early nineteenth century, poor Africans found themselves with no land and much of their traditional support structure destroyed. Those who converted to Christianity and learned its tenets best were not guaranteed a more secure position in life, and certainly would not be accepted into colonial administration or bureaucracy (despite missionary claims of the long term goals of Europeanisation) but they were certainly more likely to receive assistance or to gain work as translators and the like. As such, literacy was essential. ${ }^{34}$ While conflict between missionaries and settlers would continue for decades, the importance of church recognition of the settlers became increasingly important. Whatever the arguments over doctrine between settlers and missionaries, the settlers regarded themselves as Christians. The need for regular prayer, baptisms, and other related functions of the church hierarchy was strong, and much of the conflict between the two over the conversion of black Africans can perhaps be attributed to a measure of resentment felt by the settlers towards new converts. ${ }^{35}$ Settlers might expect to see a roving priest every few years, and would need to have potentially dozens of baptisms performed in a very short time, whereas converted African tribes could often expect year round church presence. ${ }^{36}$

Despite, or perhaps in part thanks to, these issues the culture amongst settler communities certainly began to change in the middle of the century. Whereas it had long been common amongst Boer communities in particular for men to accept illegitimate children by African mothers as their own, this tradition came to a somewhat abrupt end. Up until this point, "whiteness" was less based upon ancestry and far more upon social acceptance: if a white parent accepted a child from an African woman as white, the community accepted the child as well. ${ }^{37}$ Now this was no longer the case, and in a presaging of the later rigidity of the apartheid system, whiteness became something which was based (in theory) solely upon one's ancestry. While never identified explicitly as the cause, reading between the lines of British contempt for Boers in contemporary writings can lead to the conclusion that the "baseness" of settler communities was intrinsically linked to this interbreeding between settlers and the local Africans, and it is striking that by the end of the century the Boers had become conceived of in very different terms. While certainly still a "baser" race in British racial doctrine, worldwide they were regarded as being as white and properly Christian as any. One need look no further than the close association between the Boer Republics and the Empire of Germany, in light of the emerging concepts of racial purity and nationalism which were emerging there.

\section{Coda}

As society changed along the Cape frontier the role of missionaries became somewhat less intrinsic to cultural exchange, with many of the most powerful and traditional African societies following the route of Xhosa. Many communities now had permanent churches, and the role of missionaries gradually shifted from warriors of God by saving souls to community leaders and pastors. While

\footnotetext{
32 Elbourne, Blood Ground, 100-1.

33 Ibid., 315.

34 Ibid., 271.

35 Ibid., 303.

36 Ibid., 132.

${ }^{37}$ Newton-King, Masters and Servants, 208.
} 
always somewhat distanced from direct affiliation with colonial officials, the knowledge of language and culture which many missionaries now possessed made them useful to those from the Colonial Office, and some would find themselves in positions in the colonial government as advisors and translators. While perhaps not the earth shaking role which some had envisioned as young men in England and elsewhere, they were nonetheless able to have an influence upon the later phase of colonial takeover. Most would have been unlikely to find this more direct takeover a bad thing, as the coming light of European civilisation could never be a bad thing. However, the more humanitarian bent of their worldview would help to temper the more aggressive tendencies of the military governors. After all, it was in their best interests to keep their converts in relatively good stead. For what is a pastor without his flock?

\section{Conclusions}

The role of missionary societies in southern Africa is a controversial one. In many respects, their stated goals were admirable: the creation of a peaceful society which had no internecine warfare, the education and uplift of the people, and so forth. But in practice, missionaries would fill roles very similar to, and often interchangeable with, secular European explorers and diplomats, using and manipulating the Africans they encountered as befit them best. The quasi-apocalyptic vision of most mission societies in Africa was in many respects in tune with the mood of Africans. Seeing their traditional beliefs and social structures crumbling around them, it is small wonder that the allure of good to come from this change was gripping. By the same token, it is little surprise that the spreading acceptance of such beliefs would leave room for change, or that Africans might adapt elements of the Christian End of Days to their theology, with Africans as the warriors of God against the rampant hordes of the coming white men. Whenever cultures interact on such a widespread and fundamental level, chaotic reorganisation is inevitably the result, and whatever the intended goals of missionary activity in southern Africa, they found themselves on the vanguard of this change, spreading European thought and languages and opening doorways for further societal change and conquest. In the end, the war was not between God and Satan for the souls of A fricans,

it was between Europe and Africa for the hearts and minds of the people, and the end result of that battle is still undecided to this day. 


\section{Bibliography}

Brendon, Piers. The Decline and Fall of the British Empire, 1781-1997. London: Random House, 2007.

Elbourne, Elizabeth. Blood Ground: Colonialism, Missions, and the Contest for Christianity in the Cape Colony and Britain 1799-1853. Montreal: McGill-Queen's University Press, 2002.

Etherington, Norman. The Great Treks: The Transformation of Southern Africa 1815-1854. London: Pearson Education Limited, 2001.

Levine, Roger S. A Living Man from Africa: Jan Tzatroe, Xhosa Chief and Missionary, and the Making of NineteenthCentury South Africa. New Haven: Yale University Press, 2011.

Meredith, Martin. Diamonds, Gold and War: The British, the Boers, and the Making of South Africa. New York: Public Affairs, 2007.

Newton-King, Susan. Masters and Servants on the Cape Eastern Frontier. Cambridge: Cambridge University Press, 1999.

Peires, J.B . The Dead Will Arise: Nongqawnse and the Great Xhosa Cattle Killing Movement of 1856-7. Bloomington: Indiana University Press, 1989.

Porter, Bernard. The Lion's Share: A Short History of British Imperialism, 1850-2004, 4th ed. Edinburgh Gate: Pearson Education Limited, 2004.

Thompson, Leonard. A History of South Africa. New Haven: Yale University Press, 2000.

Vansina, Jan. "A Clash of Cultures: African Minds in the Colonial Era." African History: From Earliest Times to Independence 2nd ed. Eds. Philip Curtin, Steven Feierman, Leonard Thompson, Jan Vansina. Essex: Pearson Education Limited, 1995. 